\title{
STUDY OF TRENDS IN CONCENTRATIONS OF BASIC AIR POLLUTANTS IN THE MALOPOLSKA PROVINCE
}

\begin{abstract}
The purpose of the paper was to analyse the trends observed at air monitoring stations in the Malopolska Province - one of the most polluted regions in Poland. The study was carried out on the basis of long-term measurement data registered at five selected stations of automatic monitoring of air quality in the Malopolska Province. Trends evaluation was made on the basis of mean annual concentrations, taken from the database of the Chief Inspectorate for Environmental Protection in Poland. Separately for each basic air pollutant, such as $\mathrm{SO}_{2}, \mathrm{NO}_{2}, \mathrm{NO}_{\mathrm{x}}, \mathrm{CO}, \mathrm{PM} 10$ and $\mathrm{O}_{3}$, trend lines and their linear equations were determined to illustrate the direction of changes in concentrations. The obtained equations of the trend lines indicate the threat to the environment in the Malopolska Province. Based on the results obtained it can be concluded that for recent years there has been observed the concentration decrease of main air pollutants, except of tropospheric ozone.
\end{abstract}

Keywords: air monitoring, Malopolska Province, air pollutants, long-term trends

\section{Introduction}

Air pollution is considered as one of the main factors affecting the health of the population. It can cause negative changes in the respiratory and circulatory systems, even when concentrations do not exceed permissible levels [1-4]. According to World Health Organization estimates, about 7 million people died in 2012 due to insufficient air quality, which indicates a significant threat caused by air pollution [5]. It should be highlighted that in many European countries PM10 (particulate matter), $\mathrm{NO}_{2}$, and $\mathrm{O}_{3}$ concentrations will still exceed the permissible limits in 2020 [6].

The combustion of fuels is considered as the main source of gaseous and dust pollution [7]. It is believed that main anthropogenic sources are mobile and stationary combustion sources. Nitrogen oxide - emitted as NO - rapidly reacts with ozone or radicals in the atmosphere producing $\mathrm{NO}_{2}$. $\mathrm{CO}$ is formed in reaction of incomplete combustion, which major source is the road traffic transport. $\mathrm{SO}_{2}$ takes the form of a colourless gas with penetrating odour. With particulate matter it is the main ingredient causing winter-time smog. $\mathrm{SO}_{2}$ is produced by combustion of fossil fuels containing sulphur (especially coal, which can contain up to $7 \%$ sulphur by weight) $[8,9]$. Limitation $\mathrm{SO}_{2}$ and $\mathrm{NO}_{\mathrm{x}}$ emissions may reduce the occurrence of acid rains. Acid rains cause changes in soil chemical parameters and reduce the soil fertility. They negatively affect the growth and productivity of plants [10]. Ozone is a reactive, colourless gas which is not directly emitted. In the

\footnotetext{
${ }^{1}$ Faculty of Infrastructure and Environment, Czestochowa University of Technology, ul. J.H. Dąbrowskiego 69, 42-200 Częstochowa, Poland

*Corresponding author: szymon@is.pcz.czest.pl
} 
troposphere it is formed by a photochemical decay of nitrogen oxide $\mathrm{NO}_{2}$ in the presence of VOCs arising mainly from mobile sources (road transport) and stationary sources (power plants). It is possible to distinguish two kinds of ozone: stratospheric ozone, formed in the stratosphere from dissociation of the oxygen molecules with UV light, and tropospheric ozone, occurs as a secondary pollutant in the troposphere after $\mathrm{NO}_{2}$ photodissociation $[9,11]$. Epidemiologic studies prove that constant exposure to ambient high levels of $\mathrm{O}_{3}$ causes increases in mortality and hospital admissions for respiratory disease [11]. The main source of particulate matter in the air is burning of fossil fuels from a various of anthropogenic activities, like industry, power generation, road transport. Particulate matter can also be formed in natural processes, for example as a result of forest fires or volcanic eruptions. Chronic exposure to increased levels of airborne dust can cause cardiovascular disease and thus shorten life expectancy [12].

In Poland, an institution dealing with monitoring of the air pollution level is Chief Inspectorate of Environmental Protection [13]. It manages the entire air monitoring system in Poland. The system collects data of concentration levels of air pollutants. The data are collected according to standardized measurement methods at air monitoring stations, located in chosen cities. The locations of the measuring stations are carefully selected. The air monitoring station should be located in such a way that the registered pollutant concentration levels reflect the influence of various local sources of air pollution. The pollution level should not be dominated by a single source, unless such a situation is typical for a larger urban area. Typically, air sampling points are representative of a few square kilometres.

Long-term measurement series allow to determine trends and describe them by mathematical equations. For longer measurement series, the impact of any climatic disturbance is minimized. In the case of shorter time series, e.g. 2-3 year ones, seasonal weather anomalies can strongly influence the course of trend. Chief Inspectorate of Environmental Protection is obliged to issue annual reports assessing air quality in individual regions of Poland. Reports from 5-year periods are also published. These reports are devoted to the assessment of compliance with air quality standards in the regions. There is no information about long-term changes in them. Therefore, there is an information gap that the authors of this paper are trying to fill.

The purpose of the analysis undertaken was to determine trends of changes in air pollution concentrations in the Malopolska Province - one of the most polluted regions in Poland. Long-term time series of concentration levels of basic air pollutants such as $\mathrm{SO}_{2}$, $\mathrm{NO}_{2}, \mathrm{NO}_{\mathrm{x}}, \mathrm{CO}, \mathrm{PM} 10$ and $\mathrm{O}_{3}$, registered at five automatic air monitoring stations in the Malopolska Province, were used in the study. The first aim of the examination was to obtain linear trends and their mathematical equations The second one was to answer the question how the air quality had changed in time, and to indicate the threat to the environment in the Malopolska Province.

\section{Methodology}

The research was based on annual average concentrations of basic air pollutants - $\mathrm{SO}_{2}$, $\mathrm{NO}_{2}, \mathrm{NO}_{\mathrm{x}}, \mathrm{CO}, \mathrm{PM} 10$ and $\mathrm{O}_{3}$ - obtained from the database of Chief Inspectorate of Environmental Protection [14]. The data from five stations of automatic monitoring of the Malopolska Province, located in Krakow, Zakopane, Tarnow and Szymbark, were taken into account. The selection of specific stations was dictated by the availability of obtaining 
possibly complete measurement data. The station in Szymbark, representing the rural area, was chosen to illustrate the contrast between background concentrations and concentrations in more urbanized areas. The data comes from the period 2001-2017, but not all measurements cover the entire period.

Table 1 presents the characteristics of the considered air quality monitoring stations location, type of station, type of area represented by the station, geographical coordinates and local population. Figure 1 shows the location map of considered air monitoring stations.

Table 1

The description of the air monitoring stations

\begin{tabular}{|c|c|c|c|c|c|}
\hline $\begin{array}{c}\text { Monitoring } \\
\text { station }\end{array}$ & Address/localization & Station type & Area type & $\begin{array}{c}\text { Geographical } \\
\text { coordinates }\end{array}$ & $\begin{array}{c}\text { Local } \\
\text { population }\end{array}$ \\
\hline $\begin{array}{c}\text { Krakow- } \\
\text { Krasinskiego }\end{array}$ & $\begin{array}{l}\text { Krakow, al. } \\
\text { Krasinskiego }\end{array}$ & communication & urban & $\begin{array}{l}\Phi 50.057678 \\
\lambda 19.926189 \\
\end{array}$ & $\begin{array}{c}771069 \\
(2018) \\
\end{array}$ \\
\hline $\begin{array}{c}\text { Krakow- } \\
\text { Bulwarowa }\end{array}$ & $\begin{array}{l}\text { Krakow, ul. } \\
\text { Bulwarowa }\end{array}$ & industrial & urban & $\begin{array}{l}\Phi 50.069308 \\
\lambda 20.053492 \\
\end{array}$ & $\begin{array}{c}771069 \\
(2018) \\
\end{array}$ \\
\hline Zakopane & $\begin{array}{l}\text { Zakopane, ul. } \\
\text { Sienkiewicza }\end{array}$ & $\begin{array}{c}\text { urban } \\
\text { background }\end{array}$ & urban & $\begin{array}{l}\Phi 49.293564 \\
\lambda 19.960083\end{array}$ & $\begin{array}{l}109062 \\
(2018)\end{array}$ \\
\hline Tarnow & $\begin{array}{l}\text { Tarnow, ul. Bitwy } \\
\text { pod Studziankami }\end{array}$ & $\begin{array}{c}\text { urban } \\
\text { background }\end{array}$ & urban & $\begin{array}{l}\Phi 50.020169 \\
\lambda 21.004167\end{array}$ & $\begin{array}{l}27191 \\
(2018)\end{array}$ \\
\hline Szymbark & Szymbark & $\begin{array}{c}\text { rural } \\
\text { background }\end{array}$ & rural & $\begin{array}{l}\Phi 49.633714 \\
\lambda 21.116833\end{array}$ & $\begin{array}{l}3133 \\
(2011)\end{array}$ \\
\hline
\end{tabular}

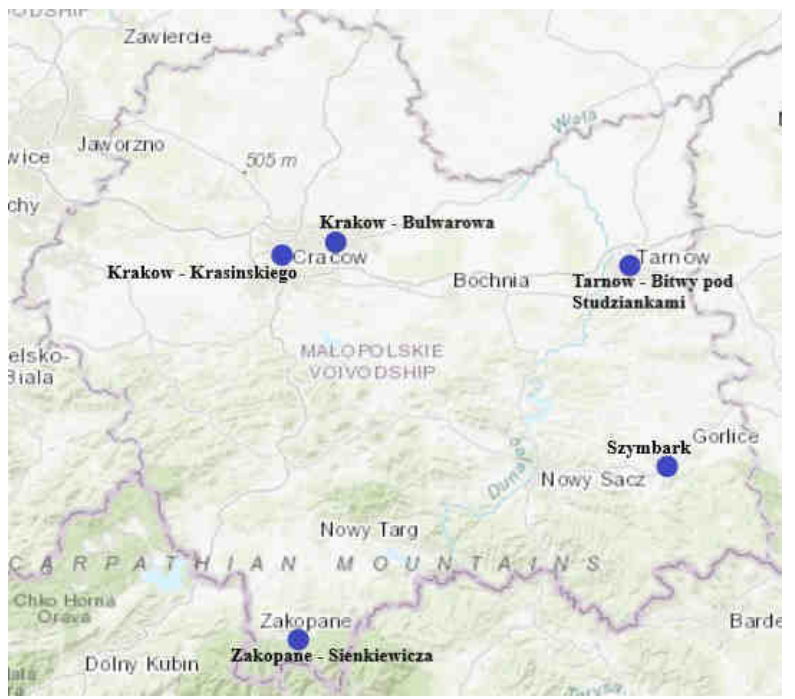

Fig. 1. Location of selected air quality monitoring stations in the Malopolska Province [14]

Measurements of air pollution in the Malopolska Voivodship were performed taking into account the reference methodologies specified in the Regulation of the Minister of the Environment of September 13, 2012: On the assessment of the levels of substances in the air [15]. These reference methodologies are consistent with the EU Directive 2008/50/EC [16]. 
Reference method for the measurement were described in EN standards:

- for $\mathrm{SO}_{2}$ in EN 14212:2012: Ambient air - Standard method for the measurement of the concentration of sulphur dioxide by ultraviolet fluorescence [17];

- for $\mathrm{NO}_{2}$ and $\mathrm{NO}$ in EN 14211:2012: Ambient air - Standard method for the measurement of the concentration of nitrogen dioxide and nitrogen monoxide by chemiluminescence [18];

- $\quad$ for PM10 in EN12341:2014: Ambient Air - standard gravimetric measurement method for the determination of the PM10 or PM2.5 mass concentration of suspended particulate matter [19];

- $\quad$ for CO in EN 14626:2012: Ambient Air - Standard method for the measurement of the concentration of carbon monoxide by non-dispersive infrared spectroscopy [20];

- for $\mathrm{O}_{3}$ in EN 14625:2012: Ambient Air - Standard method for the measurement of the concentration of ozone by ultraviolet photometry [21].

The measuring devices of each air monitoring station were placed in a measuring kiosk and were equipped with auto-calibration systems.

The first stage of the analysis was to create time-series of annual concentration averages. Then, trend lines were matched to long-term time-series courses with the least squares method. The aim of the work was to obtain linear trends and their mathematical equations in the form (1):

$$
y=a x+b
$$

where $y$ was the concentration, $a$ was the slope of the trend line, $x$ was the number of year in time-series, $b$ was the intercept (the value of concentration at the beginning of the measurement period).

Intercepts of the trend equations show the concentration level, while slopes of the trend equations indicate the direction of changes in the concentration level. The slopes can be interpreted as the annual increases or decreases of concentration.

\section{Results}

Figures 2-7 presents the courses of annual average concentrations recorded at the selected air monitoring stations, separately for $\mathrm{SO}_{2}, \mathrm{NO}_{2}, \mathrm{NO}_{\mathrm{x}}, \mathrm{CO}, \mathrm{PM} 10, \mathrm{O}_{3}$. Linear equations describing the trends were fitted to each of the course.

Table 2 contains the equations of the trend lines for the individual stations and the specified measurement periods. Figure 2 presents changes in $\mathrm{SO}_{2}$ concentrations at five monitoring stations over various time periods. The highest concentration levels were observed at the stations in Krakow. The lowest level occurred in Szymbark. For each monitoring station, the decrease in $\mathrm{SO}_{2}$ concentration is observed, the strongest downward trend appear in the case of concentrations recorded at the Krakow-Krasinskiego station.

Table 2

The trend line equations for $\mathrm{SO}_{2}$ concentration specified for the individual monitoring stations

\begin{tabular}{|c|c|c|c|}
\hline Pollutant & Monitoring station & Trend equation & Measurement period \\
\hline \multirow{4}{*}{$\mathrm{SO}_{2}$} & Krakow-Krasinskiego & $y=-1.144 x+22.8$ & $2001-2014$ \\
\cline { 2 - 4 } & Krakow-Bulwarowa & $y=-0.581 x+16.0$ & $2001-2017$ \\
\cline { 2 - 4 } & Tarnow & $y=-0.529 x+10.8$ & $2010-2017$ \\
\cline { 2 - 4 } & Zakopane & $y=-0.449 x+14.8$ & $2004-2017$ \\
\cline { 2 - 4 } & Szymbark & $y=-0.307 x+6.6$ & $2005-2017$ \\
\hline
\end{tabular}


a)

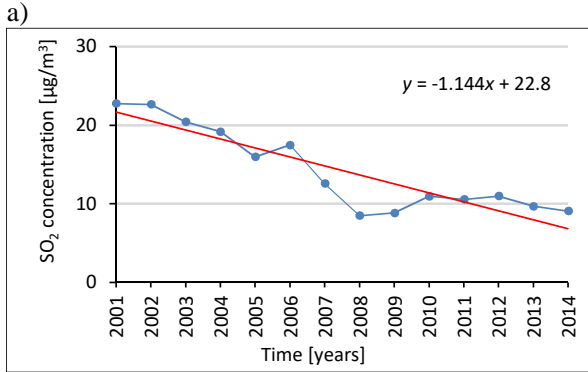

c)

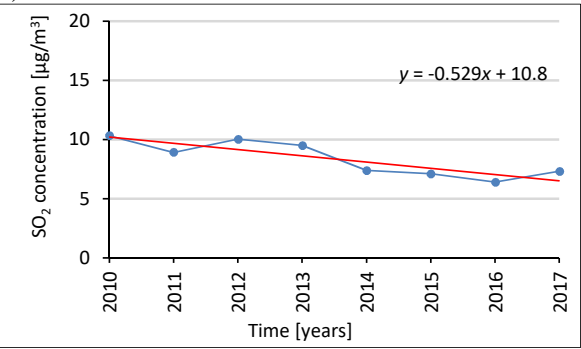

b)

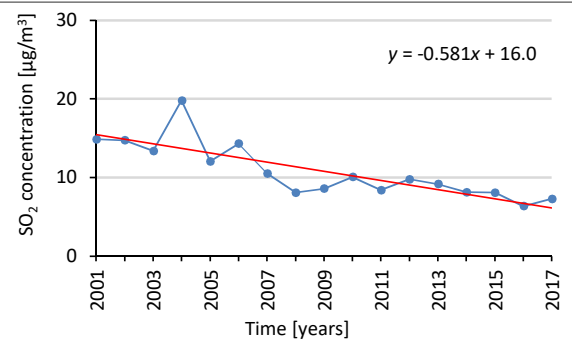

d)

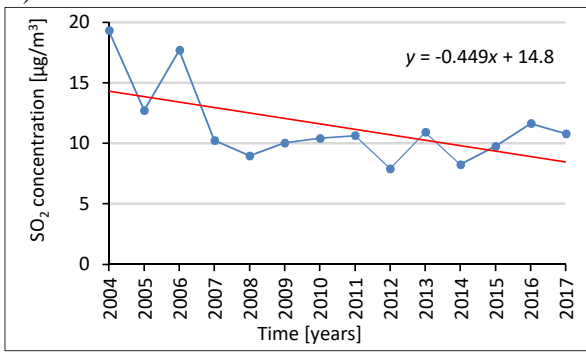

e)

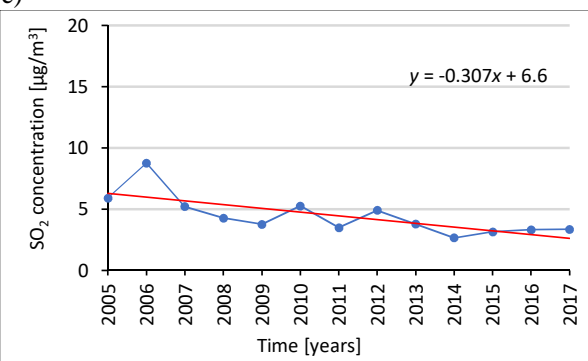

Fig. 2. The courses of $\mathrm{SO}_{2}$ annual concentrations at the specified air monitoring stations: a) Krakow-Krasinskiego; b) Krakow-Bulwarowa; c) Tarnow; d) Zakopane; e) Szymbark; annual concentration $\longrightarrow$ trend line

The trend line equations for $\mathrm{NO}_{2}$ concentration specified for the individual monitoring stations

\begin{tabular}{|c|c|c|c|}
\hline Pollutant & Monitoring station & Trend equation & Measurement period \\
\hline \multirow{4}{*}{$\mathrm{NO}_{2}$} & Krakow-Krasinskiego & $y=-0.175 x+67.3$ & $2001-2017$ \\
\cline { 2 - 4 } & Krakow-Bulwarowa & $y=-0.269 x+31.8$ & $2001-2017$ \\
\cline { 2 - 4 } & Tarnow & $y=-0.377 x+24.9$ & $2010-2017$ \\
\cline { 2 - 4 } & Zakopane & $y=-0.096 x+21.1$ & $2004-2017$ \\
\cline { 2 - 4 } & Szymbark & $y=-0.163 x+8.3$ & $2006-2017$ \\
\hline
\end{tabular}

Table 3 contains the equations of the trend lines for the individual stations and the measurement periods. Figure 3 presents changes of $\mathrm{NO}_{2}$ concentrations. The highest concentration level was recorded at the station of communication type in Krakow-Krasinskiego. That's not surprising, because $\mathrm{NO}_{2}$ is one of the specific pollutants emitted by cars. However, the $\mathrm{NO}_{2}$ concentration level was so high at this place that the limit value of $40 \mu \mathrm{g} / \mathrm{m}^{3}$ was permanently exceeded. At the other stations the 
concentration levels were lower and the air quality standards were not exceeded. The lowest concentrations were recorded in Szymbark. At all stations the decrease in $\mathrm{NO}_{2}$ concentrations was observed.

a)

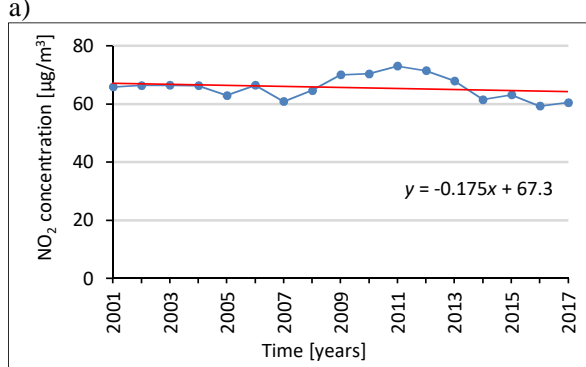

c)

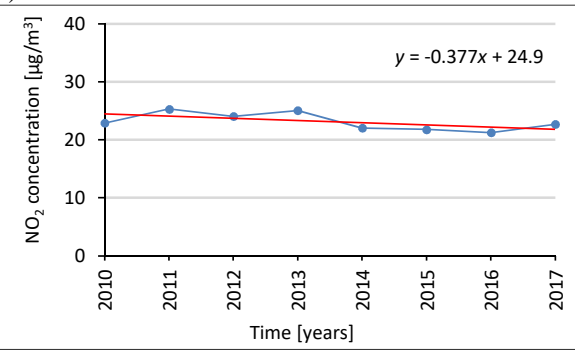

b)

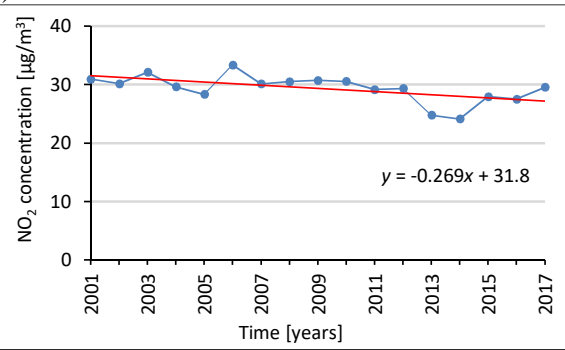

d)

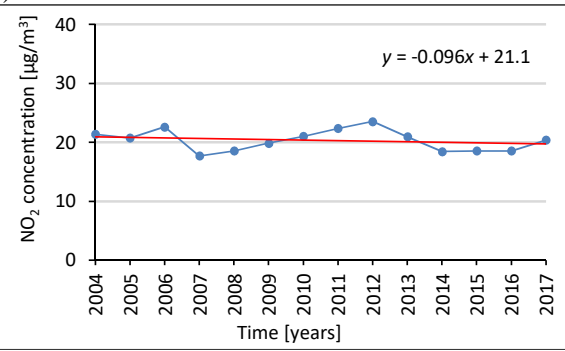

e)

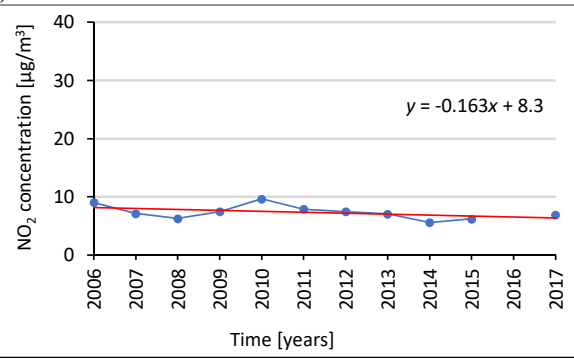

Fig. 3. The courses of $\mathrm{NO}_{2}$ annual concentrations at the specified air monitoring stations: a) Krakow-Krasinskiego; b) Krakow-Bulwarowa; c) Tarnow; d) Zakopane; e) Szymbark; annual concentration trend line

The trend line equations for $\mathrm{NO}_{\mathrm{x}}$ concentration specified for the individual monitoring stations

\begin{tabular}{|c|c|c|c|}
\hline Pollutant & Monitoring station & Trend equation & Measurement period \\
\hline \multirow{4}{*}{ NO $_{\mathrm{x}}$} & Krakow-Krasinskiego & $y=-1.715 x+244.8$ & $2001-2017$ \\
\cline { 2 - 4 } & Krakow-Bulwarowa & $y=-0.333 x+65.8$ & $2001-2017$ \\
\cline { 2 - 4 } & Tarnow & $y=-0.555 x+38.1$ & $2010-2017$ \\
\cline { 2 - 4 } & Zakopane & $y=-0.139 x+33.2$ & $2004-2017$ \\
\cline { 2 - 4 } & Szymbark & $y=-0.354 x+12.2$ & $2005-2017$ \\
\hline
\end{tabular}

Table 4 contains the equations of the trend lines for the individual stations and the measurement periods. Figure 4 presents changes in $\mathrm{NO}_{\mathrm{x}}$ concentrations. As in the case of 
$\mathrm{NO}_{2}$, the highest concentration level occurs at the Krakow-Krasinskiego communication station. At all stations a downward trend was observed. The highest negative slope value $\left(-1.715 \mu \mathrm{g} / \mathrm{m}^{3}\right.$ per year) was recorded at the Krakow-Krasinski station, but the highest concentrations are also found here.

a)

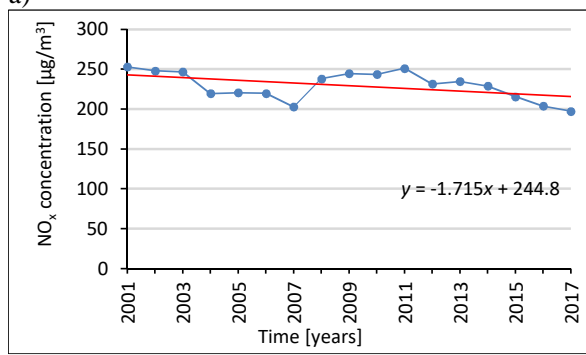

c)

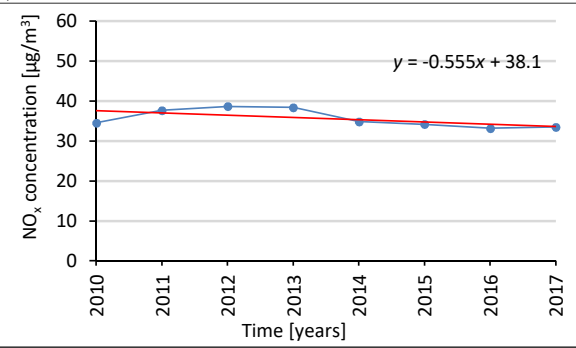

b)

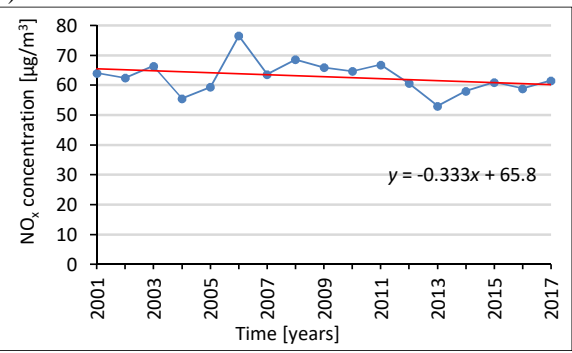

d)

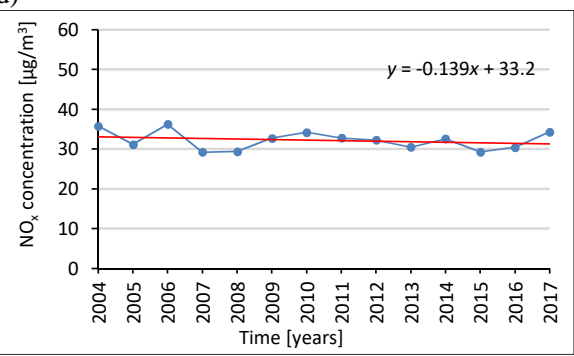

e)

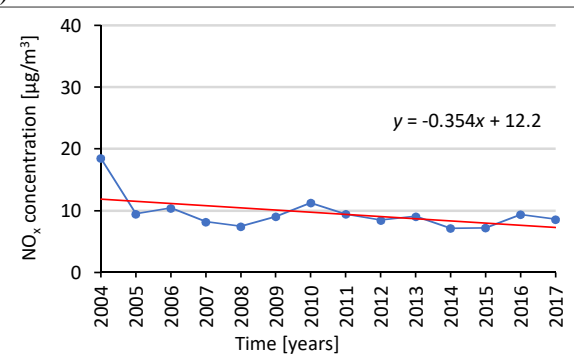

Fig. 4. The courses of $\mathrm{NO}_{\mathrm{x}}$ annual concentrations at the specified air monitoring stations: a) Krakow-Krasinskiego; b) Krakow-Bulwarowa; c) Tarnow; d) Zakopane; e) Szymbark; annual concentration trend line

The trend line equations for $\mathrm{CO}$ concentration specified for the individual monitoring stations

\begin{tabular}{|c|c|c|c|}
\hline Pollutant & Monitoring station & Trend equation & Measurement period \\
\hline \multirow{4}{*}{ CO } & Krakow-Krasinskiego & $y=-0.063 x+1.69$ & $2004-2017$ \\
\cline { 2 - 4 } & Krakow-Bulwarowa & $y=-0.013 x+0.76$ & $2004-2017$ \\
\cline { 2 - 4 } & Tarnow & $y=-0.033 x+0.52$ & $2010-2016$ \\
\cline { 2 - 4 } & Zakopane & $y=-0.022 x+0.83$ & $2004-2017$ \\
\cline { 2 - 4 } & Szymbark & - & - \\
\hline
\end{tabular}


Table 5 shows the equations of the trend lines for the individual stations and the measurement periods. Figure 5 presents changes in $\mathrm{CO}$ concentrations. At all stations the decrease in $\mathrm{CO}$ concentration was noticed, however, at the Krakow-Krasinskiego station the fall was particularly distinct - the slope value reached $-0.063 \mathrm{mg} / \mathrm{m}^{3}$ per year.

a)

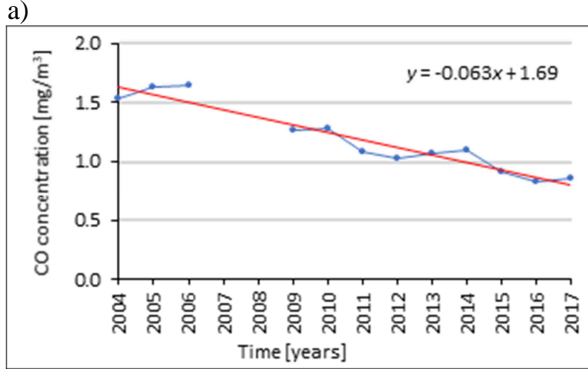

c)

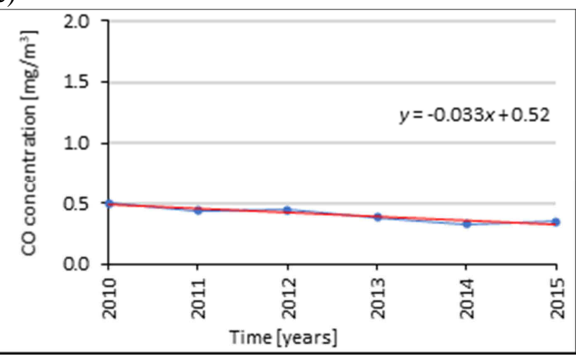

b)

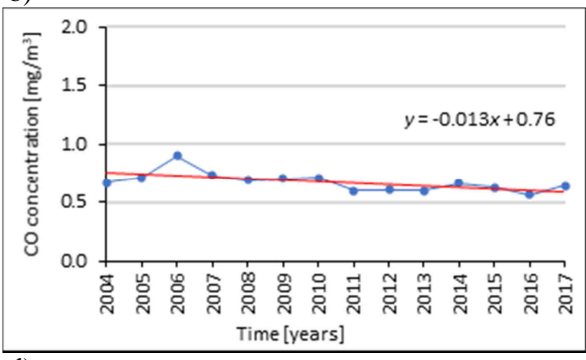

d)

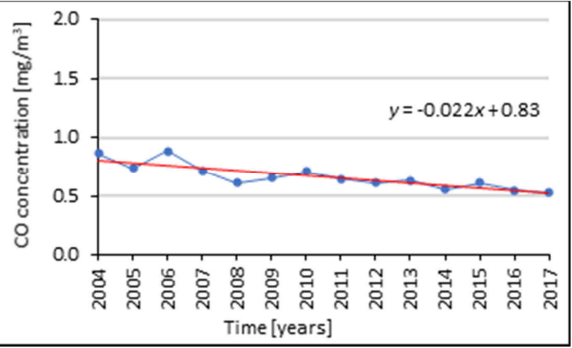

Fig. 5. The courses of $\mathrm{CO}$ annual concentrations at the specified air monitoring stations: a) Krakow-Krasinskiego; b) Krakow-Bulwarowa;

c) Tarnow;

d) Zakopane;

Table 6 contains the equations of the trend lines for 4 individual stations and the measurement periods. Figure 6 shows changes in PM10 concentrations. PM10 concentrations are high at all 4 stations. The values of concentration at the beginning of the measurement periods (the intercepts) in all cases exceeded the annual limit value $40 \mu \mathrm{g} / \mathrm{m}^{3}$, specified in the air quality standards. There was a downward trend at all monitoring stations, the largest decrease is observed at the Krakow-Krasinski station. The trend equations show that the annual PM10 concentrations decreased by about $1.2-2.1 \mu \mathrm{g} / \mathrm{m}^{3}$ per year. Such rapid drops mean that the limit value was currently exceeded at only 2 air monitoring stations in Krakow, and the air quality continued to improve.

Table 6

The trend line equations for PM10 concentration specified for the individual monitoring stations

\begin{tabular}{|c|c|c|c|}
\hline Pollutant & Monitoring station & Trend equation & Measurement period \\
\hline \multirow{4}{*}{ PM10 } & Krakow-Krasinskiego & $y=-2.085 x+90.0$ & $2003-2017$ \\
\cline { 2 - 4 } & Krakow-Bulwarowa & $y=-1.215 x+65.2$ & $2003-2017$ \\
\cline { 2 - 4 } & Tarnow & $y=-1.922 x+43.1$ & $2010-2017$ \\
\cline { 2 - 4 } & Zakopane & $y=-1.815 x+57.1$ & $2004-2017$ \\
\cline { 2 - 4 } & Szymbark & - & - \\
\hline
\end{tabular}


a)

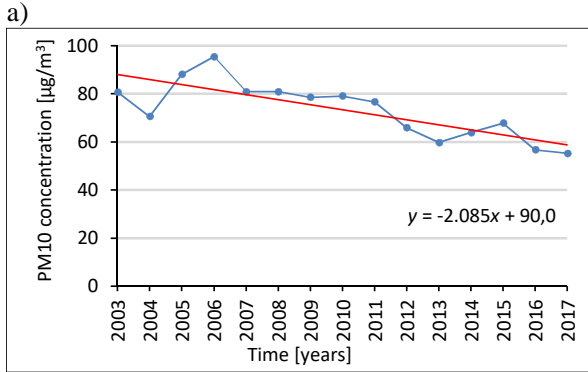

c)

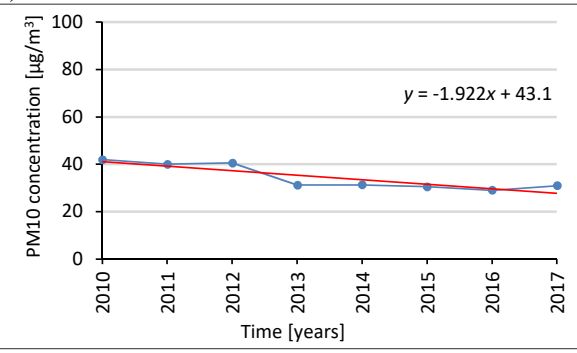

b)

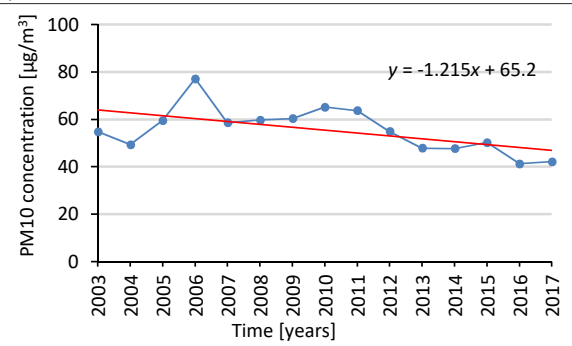

d)

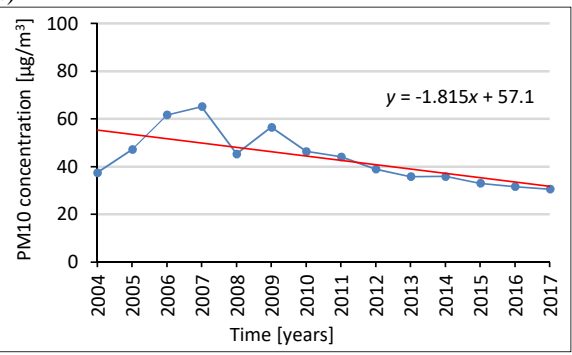

Fig. 6. The courses of PM10 annual concentrations at the specified air monitoring stations: a) Krakow-Krasinskiego; b) Krakow-Bulwarowa; c) Tarnow; d) Zakopane; annual concentration $\longrightarrow$ trend line

a)

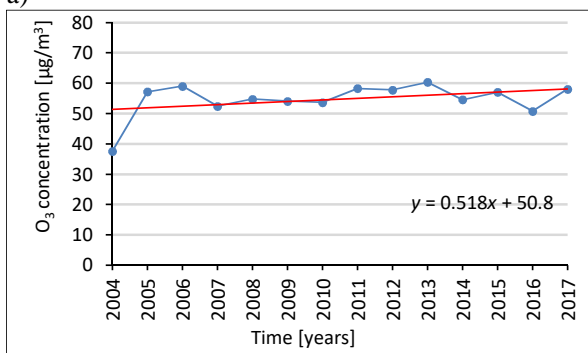

b)

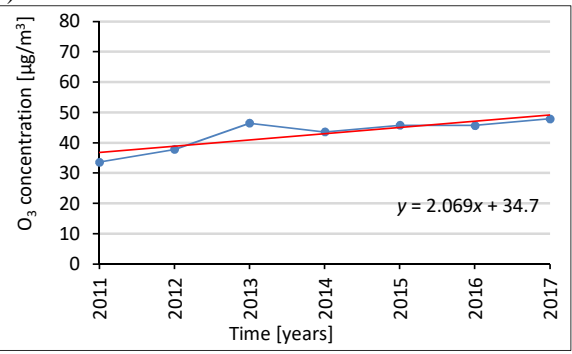

c)

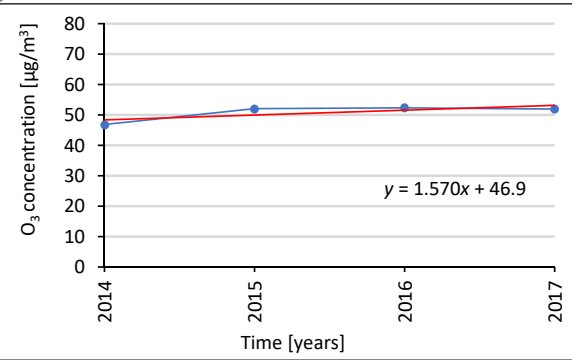

Fig. 7. The courses of $\mathrm{O}_{3}$ annual concentrations at the specified air monitoring stations: a) Szymbark; b) Tarnow; c) Zakopane; annual concentration trend line 
Table 7 contains the equations of the trend lines for the individual stations and the measurement periods. Figure 7 shows changes in $\mathrm{O}_{3}$ concentrations. Ozone concentration was measured at three stations (Zakopane, Tarnow, Szymbark). At all the stations the increase in $\mathrm{O}_{3}$ concentrations was recorded. At the station located in Tarnow, the annual rise of $\mathrm{O}_{3}$ concentrations was the highest (the slope value was equal ab. $2.1 \mu \mathrm{g} / \mathrm{m}^{3}$ per year).

Table 7

The trend line equations for $\mathrm{O}_{3}$ concentration specified for the individual monitoring stations

\begin{tabular}{|c|c|c|c|}
\hline Pollutant & Monitoring station & Trend equation & Measurement period \\
\hline \multirow{4}{*}{$\mathrm{O}_{3}$} & Krakow-Krasinskiego & - & - \\
\cline { 2 - 4 } & Krakow-Bulwarowa & - & - \\
\cline { 2 - 4 } & Szymbark & $y=0.518 x+50.8$ & $2005-2017$ \\
\cline { 2 - 4 } & Tarnow & $y=2.069 x+34.7$ & $2011-2017$ \\
\cline { 2 - 4 } & Zakopane & $y=1.570 x+46.9$ & $2014-2017$ \\
\hline
\end{tabular}

\section{Discussion}

Considering changes in concentrations of air pollutants in the Malopolska Province, it can be concluded that the air quality has gradually improved in this region studied. For $\mathrm{SO}_{2}$, $\mathrm{CO}$ and PM10 concentration levels, the changes are especially evident. At the monitoring stations considered herein, the annual drops of concentrations are equal from 0.307 to $1.144 \mu \mathrm{g} / \mathrm{m}^{3}$ for $\mathrm{SO}_{2}$, from 0.013 to $0.063 \mathrm{mg} / \mathrm{m}^{3}$ for $\mathrm{CO}$, and from 1.215 to $2.085 \mu \mathrm{g} / \mathrm{m}^{3}$ for PM10. The drops in the concentrations of these pollutants in the most polluted location the Krakow-Krasinskiego station - are particularly satisfactory. According to the European Environment Agency reports, the most important problem in Poland are exceeded particulate matter concentrations [22]. In the locations studied the PM10 concentrations has declined in recent years for which the study was. The annual limit value $\left(40 \mu \mathrm{g} / \mathrm{m}^{3}\right)$ is currently exceeded only at the both monitoring stations in Krakow. Krakow Agglomeration is indicated as the main area within the region where PM concentration limits are significantly exceeded [23]. Similar trends for $\mathrm{SO}_{2}, \mathrm{CO}$ and PM10 concentration levels are observed in other regions of Poland: in Upper Silesia and in the Masovian Voivodship [24-26]. These pollutants are generally formed during combustion processes, and the amount of their emission depends on the quality of the fuel and the combustion process. The decreases of PM10 and $\mathrm{SO}_{2}$ concentrations may be the result of gradual reduction in the use of poor quality solid fuels.

The drops of $\mathrm{NO}_{2}$ concentrations are not so apparent. The decrease in $\mathrm{NO}_{\mathrm{x}}$ concentration at the Krakow-Krasinskiego station was relatively high (the slope value $\mathrm{a}=-1.715$ ), while the decrease in $\mathrm{NO}_{2}$ concentration at this station was less significant $(\mathrm{a}=-0.175)$. Since $\mathrm{NO}$ is one of the two components of $\mathrm{NO}_{\mathrm{x}}$, this means that there is the greater decrease in $\mathrm{NO}$ concentration than in concentration of $\mathrm{NO}_{2}$. $\mathrm{NO}$ is the major component of $\mathrm{NO}_{\mathrm{x}}$ in vehicle exhaust gases. However, $\mathrm{NO}$ quickly oxidizes to $\mathrm{NO}_{2}$ in the air. The decrease in NO concentration may be a direct effect of a reduction of the traffic emissions in the immediate vicinity of the air monitoring station.

The changes in $\mathrm{O}_{3}$ concentrations are worrying. It is reported that the long-term objectives for 8-hour $\mathrm{O}_{3}$ concentrations $\left(120 \mu \mathrm{g} / \mathrm{m}^{3}\right.$ not to be exceeded) is not achieved in the Malopolska Region [23]. The increase in ozone concentration levels means that the limit value $120 \mu \mathrm{g} / \mathrm{m}^{3}$ may be exceeded more frequently in the future. 


\section{Conclusion}

The long-term observations of concentration levels of the basic pollutants, measured at five air monitoring stations in the Malopolska Province, allow to formulate the following conclusions:

1. Concentrations of most of air pollutants studied tend to decrease.

2. Only in case of tropospheric $\mathrm{O}_{3}$ the gradual concentration increase is observed. In the future, the increase of $\mathrm{O}_{3}$ concentrations is expected in the region.

3. The largest decrease in the level of air concentrations is recorded for $\mathrm{SO}_{2}, \mathrm{CO}$, and PM10 concentrations.

4. The slightly decreasing trends are observed for $\mathrm{NO}_{2}$ and $\mathrm{NO}_{\mathrm{x}}$ concentrations.

The above conclusions refer to all five air monitoring stations taken into consideration. The analysis did not include data from all measuring stations in the region. When selecting the stations, the completeness of measurement data in the long term was taken into account. It should be also noted that only the main air pollutants were considered.

\section{Acknowledgments}

The scientific research was funded by the statute subvention of Czestochowa University of Technology, Faculty of Infrastructure and Environment. Part of the research has been carried out within research projects of Czestochowa University of Technology BS/MN-400/301/19 and BS/PB-400/301/19.

\section{References}

[1] Hoffmann B, Roebbel N, Gumy S, Forastiere F, Brunekreef B, Jarosinska D, et al. Europ Respiratory J. 2020;56.2002575. DOI: 10.1183/13993003.02575-2020.

[2] Gurjar BR, Molina LT, Ojha CSP. Air pollution: health and environmental impacts. Boca Raton: CRC Press; 2010. ISBN: 9780429075599 . DOI: 10.1201/EBK1439809624.

[3] Adamkiewicz G, Liddie J, Gaffin JM. Clin Chest Med. 2020;41(4):809-24. DOI: 10.1016/j.ccm.2020.08.013.

[4] Finicelli M, Squillaro T, Galderisi U, Peluso G. Int J Mol Sci. 2020;30;21(19):7221. DOI: 10.3390/ijms21197221.

[5] World Health Organization. 7 Million Premature Deaths Annually Linked to Air Pollution. Available from: www.who.int/mediacentre/news/releases/2014/air-pollution/en. Date last updated: March 25, 2014.

[6] Maesano I. Europ Respiratory Rev. 2017;26:170024. DOI: 10.1183/16000617.0024-2017.

[7] Katsouyanni K. British Medical Bull. 2003;68.143-56. DOI: 10.1093/bmb/ldg028.

[8] Kampa M, Castanas E. Environ Pollut. 2008;151.2.362-7. DOI: 10.1016/j.envpol.2007.06.012.

[9] Tiwary A, Williams I, Colls J. Air Pollution: Measurement. Modelling and Mitigation. Fourth Edition. Boca Raton: CRC Press; 2018. ISBN: 9781498719452. DOI: 10.1201/9780429469985.

[10] Singh A, Agrawal M. J Environ Biol. 2008;29.1.15-24. Available from: http://www.jeb.co.in/journal_issues/200801_jan08/paper_02.pdf.

[11] Uysal N, Schapira RM. Curr Opinion Pulmonary Medicine. 2003;9.2.144-50. DOI: 10.1097/00063198-200303000-00009.

[12] Brook RD, Rajagopalan S, Pope CA, Brook JR, Bhatnagar A, Diez-Roux AV. Circulation. 2010;121.21.2331-78. DOI: 10.1161/CIR.0b013e3181dbece1.

[13] Chief Inspectorate of Environmental Protection. https://www.gios.gov.pl/en/.

[14] Map and station characteristics available on the website Chief Inspectorate of Environmental Protection: Available from: powietrze.gios.gov.pl.

[15] Rozporządzenie Ministra Środowiska z dnia 13 września 2012 roku w sprawie dokonywania oceny poziomów substancji w powietrzu (Dz. U. 2012, poz. 1032 (2012). (Regulation of the Polish Minister of the Environment of September 13, 2018, On the assessment of the levels of substances in the air). Available from: http://isap.sejm.gov.pl/isap.nsf/DocDetails.xsp?id=WDU20120001032. 
[16] Directive 2008/50/EC of the European Parliament and of the Council of 21 May 2008 on ambient air quality and cleaner air for Europe, OJ L 152, 11.6.2008, 1-44. Available from: https://eur-lex.europa.eu/ legal-content/en/TXT/?uri=CELEX\%3A32008L0050.

[17] EN 14212:2012 Ambient air - Standard method for the measurement of the concentration of sulphur dioxide by ultraviolet fluorescence. Available from: http://store.uni.com/catalogo/en-14212-2012.

[18] EN 14211:2012 Ambient air - Standard method for the measurement of the concentration of nitrogen dioxide and nitrogen monoxide by chemiluminescence. Available from: https://infostore.saiglobal.com/ en-us/Standards/EN-14211-2012-346794_SAIG_CEN_CEN_792901/.

[19] EN 12341:2014 Ambient air - Standard gravimetric measurement method for the determination of the PM10 or PM2.5 mass concentration of suspended particulate matter. Available from: https://standards.iteh.ai/catalog/standards/cen/7ad508ad-33bd-4e41-942b-c52ddeb6d44d/en-12341-2014.

[20] EN 14626:2012 Ambient air. Standard method for the measurement of the concentration of carbon monoxide by non-dispersive infrared spectroscopy. Available from: https://infostore.saiglobal.com/ en-us/Standards/EN-14626-2012-325477_SAIG_CEN_CEN_750266/.

[21] EN 14625:2012 Ambient air. Standard method for the measurement of the concentration of ozone by ultraviolet photometry. Available from: https://standards.iteh.ai/catalog/standards/cen/9437d258-696a-4f6cb167-fb38250d4420/en-14625-2012.

[22] European Environment Agency, Air quality in Europe - 2018 report. No. 12/2018, Publications Office of the European Union, Luxembourg, 2018. Available from: https://op.europa.eu/en/publication-detail//publication/223e663b-1340-11e9-81b4-01aa75ed71a1/language-en.

[23] Wojewódzki Inspektorat Ochrony Środowiska w Krakowie, Ocena jakości powietrza w województwie małopolskim w 2017 roku (Assessment of air quality in the Małopolskie Voivodeship in 2017). Kraków: 2018. Available from: http://www.krakow.pios.gov.pl/Press/monitoring/powietrze/wyniki/ocena_jakosci_ powietrza_2017-malopolska.pdf.

[24] Hoffman S. E3S Web Conf. 2018;28:01013. DOI: 10.1051/e3sconf/20182801013.

[25] Hoffman S, Filak M. Proc ECOpole. 2018;12(2):483-9. DOI: 10.2429/proc.2018.12(2)047.

[26] Hoffman S. E3S Web Conf. 2019;116:00027. DOI: 10.1051/e3sconf/201911600027. 